\title{
Application of a point-of-care test for the serodiagnosis of typhoid fever in Nigeria and the need for improved diagnostics
}

\author{
Stella I. Smith ${ }^{1}$, Moses Bamidele ${ }^{1}$, Muinah Fowora ${ }^{1}$, Helen T. Goodluck ${ }^{1}$, Emmanuel A. \\ Omonigbehin ${ }^{1}$, Kehinde A. Akinsinde ${ }^{1}$, Toun Fesobi ${ }^{1}$, Rob Pastoor ${ }^{2}$, Theresia H. Abdoel ${ }^{2}$, Henk \\ L. Smits ${ }^{2}$ \\ ${ }^{1}$ Molecular Biology and Biotechnology Division, Nigerian Institute of Medical Research, P.M.B. 2013, Yaba, Lagos, \\ Nigeria \\ ${ }^{2}$ KIT Biomedical Research, Royal Tropical Institute / Koninklijk Instituut voor de Tropen (KIT), Meibergdreef 39, \\ 1105 AZ Amsterdam, The Netherlands
}

\begin{abstract}
Introduction: There is an urgent need for affordable point-of-care diagnostics for the differentiation of febrile illnesses and the confirmation of typhoid in endemic countries.

Methodology: Blood samples were collected from febrile patients with clinical suspicion of typhoid and screened for typhoid fever using the Widal and Typhi Dri Dot tests, while stool and blood samples were screened for Salmonella Typhi using the culture method as well as PCR as a confirmatory test.

Results: A high proportion of febrile patients from Lagos with clinical suspicion of typhoid fever reacted positively in a simple and rapid latex agglutination assay for typhoid fever, indicating that this illness is a common and presumably under-diagnosed health problem in this metropolis. Seropositivity was $19.2 \%$ in the rapid test compared with $22.9 \%$ in the classical Widal test. The confirmation of typhoid in these seropositive patients appeared cumbersome because of negative blood cultures and low DNA yield in molecular testing. A review of the literature revealed that in Nigeria seroprevalence rates can be high in the normal population and that pathogens other than $S$. Typhi are often isolated from the blood of seropositive febrile patients.

Conclusion: The simplicity and the relatively high specificity $(97.8 \%)$ of the rapid test as determined in a study performed in Indonesia calls for a further validation of this promising test for use in Africa.
\end{abstract}

Key words: Salmonella Typhi; typhoid fever; diagnosis; point-of-care; Nigeria

J Infect Dev Ctries 2011; 5(7):520-526.

(Received 04 April 2010 - Accepted 05 January 2011)

Copyright (C) 2011 Smith et al. This is an open-access article distributed under the Creative Commons Attribution License, which permits unrestricted use, distribution, and reproduction in any medium, provided the original work is properly cited.

\section{Introduction}

Salmonella enterica serotype Typhi (S. Typhi), the causative agent of typhoid fever, remains a major public health problem in many parts of the world, especially in areas where clean water supplies are lacking $[1,2]$. In developing countries, especially in Southeast Asia and Africa, the disease is associated with high incidences of morbidity and mortality $[1,3]$. Worldwide, an estimated 21.6 million typhoid cases occur annually causing approximately 200,000 deaths, and the annual incidence in developing countries may be as high as 100 to 1,000 cases per 100,000 [4]. In Southeast Asia, the disease is also very common among very young children, often with high rates of complications and hospitalization [5-7]. Recent data on the prevalence of typhoid fever in
Africa is lacking but in 1986 it was reported that approximately 4.36 million cases occured in an estimated population of 427 million [8].

The diagnosis of typhoid requires laboratory confirmation because other common febrile diseases may present with similar signs and symptoms. Blood culture (the gold standard) and the classical Widal agglutination test may be used for the confirmation of this disease but these methods have several limitations [2, 9-11]. The sensitivity of culture decreases with the duration of illness and culture facilities are scarce in endemic areas. The Widal test lacks both specificity and standardization. Other more recently developed serological tests such as the tube and dot rapid immunoassays have not found wide application because of the high costs and contradictory results reported in the few published 
validation studies [12-16]. We developed a simple and rapid latex agglutination assay, the $S$. Typhi Dri Dot assay, for the serodiagnosis of typhoid fever [17]. This assay is well-standardized, utilizes stabilized components that do not require refrigeration, and is performed without the need for special equipment and electricity. Combined, these characteristics allow its use outside the established laboratory and in the field.

The most commonly used test for typhoid fever in Nigeria is the classical Widal test [18]. Low agglutination titres are very common in this test and as no definite cut-off value has been established, its diagnostic value is considered low and in Nigeria treatment often is commenced indifferent of the test result. To confirm the presence of $S$. Typhi in hospitalized febrile patients in Lagos, a major city in Nigeria, we applied the latex agglutination assay. This assay has a high specificity and is highly suitable for use in a hot and humid country such as Nigeria.

\section{Methodology}

\section{Clinical specimens}

Whole blood, serum and stool samples were collected from a total of 287 febrile out-patients (mean age 40.6 years, range 7 to 78 years; male to female ratio 0.65 ) with clinical symptoms and signs of typhoid fever. Patients were entered in the study between May 2007 and December 2008 at three health centres (the Ikorodu General Hospital, the Epe General Hospital, and the Ebute Metta Health Centre) within the Lagos metropolis.

\section{Culture}

Blood culture was performed by inoculating $2 \mathrm{ml}$ of freshly collected blood into $18 \mathrm{ml}$ brain heart infusion broth (Oxoid, Basingstoke, United Kingdom) supplemented with lycoid and incubating for 7 days at $37^{\circ} \mathrm{C}$. Approximately one gram of each stool sample was inoculated into Selenite $\mathrm{F}$ broth (Oxoid) enrichment medium and incubated at $37^{\circ} \mathrm{C}$ for 24 hours. Subcultures were made onto deoxycholate agar (Oxoid) and incubated at $37^{\circ} \mathrm{C}$ for 24 hours.

\section{Serology}

The Widal test with $\mathrm{O}$ antigen (febrile antigen from Chromatest, Linear Chemicals, Barcelona, Spain) was performed and interpreted according to routine laboratory procedures. A titre of $\geq 1: 80$ was considered positive.
The $S$. Typhi Dri Dot assay consists of an agglutination card containing a dot of dried, antigenactivated latex placed on the surface in the center of the card. The card is provided in a sealed moisture resistant sachet for optimal protection of the reagent during transportation and storage. The latex has a blue colour and the assay is simply performed by placing a $10 \mu \mathrm{l}$ drop of serum next to the blue dot. The serum and the latex is then mixed using a plastic spatula provided with the card. After the latex is homogenously dispersed, the fluid is swirled by rotating the card in a near horizontal position to further mix the serum and the latex. Agglutination is readable within 30 seconds and is revealed by particulation of the latex suspension. Particulation often occurs within the first 10 to 20 seconds, and as the aggregates are usually coarse particulation is easily visible with the naked eye.

\section{Molecular detection}

DNA was prepared by proteinase $\mathrm{K}$ (Roche, Mannheim, Germany) digestion from $50 \mu$ of each whole blood sample, followed by phenol-chloroform extraction and ethanol precipitation of the waterphase. Nested PCR was performed as described by Song and coworkers [19] for the amplification of a 343-bp fragment in region VI of the fliC flagellin gene of $S$. Typhi. The first PCR was performed by the addition of $2 \mu \mathrm{l}$ of the extracted DNA to $25 \mu \mathrm{l}$ PCR mixture and amplification for 25 cycles of $94^{\circ} \mathrm{C}$ for one minute, $56^{\circ} \mathrm{C}$ for 1 minute 15 seconds and $72^{\circ} \mathrm{C}$ for 2 minutes, followed by a primer extension of 5 minutes at $72{ }^{\circ} \mathrm{C}$ using the Master Gradient Eppendorf PCR machine (Eppendorf, Hamburg, Germany). The PCR mixture consisted of standard PCR buffer (100 $\mathrm{mM}$ Tris-HCl, $\mathrm{pH} 8.3,1.5 \mathrm{mM} \mathrm{MgCl} 2,50 \mathrm{mM} \mathrm{KCl}$, $0.1 \%$ gelatin, $200 \mu \mathrm{M}$ each of all four dNTPs, and 0.625 units of Taq DNA polymerase) (Roche, Mannheim, Germany) supplemented with 25 pmol of each of the 5' (TAT GCC GCT ACA TAT GAT GAG) and 3' (TTA ACG CAG TAA AGA GAG) primers (Biomers Ulm Germany). The nested PCR was performed by the addition of $2 \mu \mathrm{l}$ of the PCR product to $20 \mu \mathrm{l}$ standard PCR buffer supplemented with 25 pmol of each of the nested 5' (ACT GCT AAA ACC ACT ACT) and 3' (TGG AGA CTT CGG TCG GGT AG) primers and amplification for 40 cycles with the same temperature cycle program as for the first reaction. The amplification products were visualized by electrophoresis in an agarose gel stained with ethidium bromide and illuminated under UV light. 


\section{Results}

Fifty-five serum samples $\quad(19.2 \% ; \quad 95 \%$ confidence interval $[\mathrm{Cl}], 15-24)$ reacted positively in the latex agglutination assay and 66 samples $(23.0 \%$; $95 \% \mathrm{CI}, 18-28)$ reacted with the $\mathrm{O}$ antigen in the Widal test at a titre of $\geq 1: 80$. These 66 samples included the 55 samples that reacted in the latex agglutination assay. Of the samples that reacted in the Widal test, 39 agglutinated at a titre of 1:80 and 27 reacted at a titre of 1:160. Forty-two other samples reacted at a titre of 1:40, illustrating the poor discriminatory value of the Widal test. All blood cultures were negative for $S$. Typhi. However, $S$. Paratyphi $\mathrm{C}$ was isolated from the blood of one patient and $S$. Choleraesuis was isolated from the stool of another patient. Nested PCR for the detection of a segment of the $S$. Typhi fliC gene [19] yielded positive results for ten $(3.5 \% ; 95 \% \mathrm{CI}, 2-7)$ blood samples, including eight samples that agglutinated in the Widal test and reacted in the latex agglutination assay. The nested PCR was negative for all Widal tests or latex agglutination assays that gave negative results. Microscopy on thick blood smears revealed the presence of malaria parasites in the blood of 53 $(18.5 \%)$ patients and, of the serum samples from these patients, ten agglutinated in the Widal test and eight reacted in the latex agglutination assay.

\section{Discussion}

Our results indicate that typhoid fever is a major cause of febrile illness in the Lagos metropolis. As typhoid fever is a serious illness that requires prompt medication, the use of an accurate diagnostic test is essential. Neither culture, the Widal test nor molecular detection, was effective in recognizing the disease. All blood cultures were negative for $S$. Typhi and PCR amplification of a segment of the gene encoding the flagella was positive in only ten cases. Interpretation of agglutination in the Widal test was cumbersome as all reactive samples agglutinated at or just one titer above or below the cut-off value. The latex agglutination assay was previously validated in a study performed in South-Sulawesi, Indonesia and has a specificity of $97.9 \%$ and a sensitivity ranging from $30.8 \%$ for samples collected during the first days of illness to $84.6 \%$ for the samples collected at a later stage [17]. The high specificity of the latex agglutination assay indicates that the majority of the febrile patients with a serum sample that agglutinated in this assay indeed suffered from typhoid fever. It is possible to explain the negative culture results by the fact that most of the patients are likely to have taken antibiotics before seeking medical care at a health centre [20]; blood culture is highly sensitive to the presence of antibiotics in the sample [21]. Although in theory molecular detection of pathogen DNA by amplification should be highly sensitive, the number of organisms at any time in the blood-stream is low and the use of antibiotics may have reduced the number to below the detection level.

A number of studies have described the use of the Widal test and blood culture for the diagnosis of typhoid fever and have investigated the presence of (multi) drug resistant $S$. Typhi in Nigeria (Table 1). The prevalence of blood culture positive patients for Salmonella spp. ranged from $12.0 \%$ to $38.9 \%$ in febrile patients with clinical suspicion of typhoid fever for different studies. The variation could be due to differences in patient definitions and entry criteria, and in culture methods, as well as due to different epidemiological conditions. S. Typhi was the most frequently isolated serovar. Other Salmonella species that were isolated included $S$. Enteritidis, $S$. Paratyphi and $S$. Typhimurium. Seroprevalence rates measured in the Widal test were generally much higher than isolation rates and from many patients with a Widal test positive result an organism other than Salmonella was isolated, showing that the Widal test is highly non-specific and likely overestimates the prevalence of Salmonella infection. High seroprevalence rates may also be found in the normal population [36] indicating that testing a single serum sample is inadequate for the confirmation of typhoid fever. Typhoid fever in Nigeria is most common in young adults and most cases are reported in the wet season [23]. Drug-resistant $S$. Typhi is very common not only to the first-line antibiotics, but it is also increasing for other antibiotics that are not commonly used in the treatment of typhoid fever.

Health care facilities in Nigeria and in many other African countries do not have access to a wellequipped diagnostic laboratory with sufficient supplies and trained staff to perform testing for common infectious diseases [38]. Therefore, the availability of point-of-care diagnostic tests that are accurate, simple, rapid. and robust will help to improve health services and patient care. Effective point-of-care tests are needed in particular for infectious diseases that are difficult to diagnose and for which effective treatment options are available. The latex agglutination test may well be suitable for the diagnosis of typhoid fever in African countries. The agglutination cards containing the dried detection reagents are individually sealed in an airtight and 
Table 1. Detection of typhoid fever patients by Widal test and blood culture in Nigeria, and (multi) drug-resistance.

\begin{tabular}{|c|c|c|c|c|c|c|c|c|c|c|}
\hline City or state & Period & $\begin{array}{l}\text { Description of } \\
\text { study group }\end{array}$ & $\begin{array}{c}\text { No. of } \\
\text { patients }\end{array}$ & $\begin{array}{c}\text { Percentage } \\
\text { Widal (O } \\
\text { antigen) test } \\
\text { positive } \\
\text { patients }^{1}\end{array}$ & $\begin{array}{c}\text { Percentage of } \\
\text { patients with a } \\
\text { positive blood } \\
\text { culture }\end{array}$ & $\begin{array}{c}\text { Percentage of } \\
\text { patients with a } \\
\text { Salmonella sp. } \\
\text { positive blood } \\
\text { culture }\end{array}$ & $\begin{array}{c}\text { Species and } \\
\text { prevalence }(\%) \text { in } \\
\text { population }\end{array}$ & $\begin{array}{c}\text { Percent drug } \\
\text { resistance } S . \\
\text { Typhi }\end{array}$ & $\begin{array}{c}\text { Percent multi } \\
\text { drug } \\
\text { resistance } S . \\
\text { Typhi }\end{array}$ & Reference \\
\hline Nsukka & 1993-1994 & $\begin{array}{l}\text { Clinical typhoid } \\
\text { suspects }\end{array}$ & 809 & $13 \%$ & $\mathrm{ND}^{2}$ & $16 \%$ & $\begin{array}{l}S . \text { Typhi }(8.4 \%) ; S \text {. } \\
\text { Typhimurium } \\
(2.7 \%) ; S . \\
\text { Enteritidis }(1.9 \%) ; \\
\text { other }(2.8 \%) \\
\end{array}$ & ND & ND & {$[22]$} \\
\hline $\begin{array}{c}\text { Lagos } \\
\text { metropolis }\end{array}$ & $\begin{array}{l}05 / 1997- \\
06 / 1998\end{array}$ & $\begin{array}{l}\text { Clinical typhoid } \\
\text { patients }\end{array}$ & 635 & $69.5 \%$ & $34.0 \%$ & $15.9 \%$ & $\begin{array}{l}S \text {. Typhi }(10.7 \%) ; S \text {. } \\
\text { Paratyphi }(2.7 \%) ; S \text {. } \\
\text { Arizona }(2.5 \%)\end{array}$ & $100 \%^{3}$ & $\mathrm{Yes}^{4}$ & {$[23,24]$} \\
\hline Lagos & $\begin{array}{l}5 / 2000- \\
6 / 2006 \\
\end{array}$ & $\begin{array}{c}\text { Pyrexia of } \\
\text { unknown origin }\end{array}$ & 103 & ND & $69.0 \%$ & $38.9 \%$ & S. Typhi (38.9\%) & $100 \%{ }^{5}$ & $61.0 \%{ }^{6}$ & {$[25]$} \\
\hline $\begin{array}{c}\text { Lagos } \\
\text { metropolis }\end{array}$ & $\begin{array}{l}\text { 10/2004- } \\
9 / 2005\end{array}$ & Febrile patients & 235 & ND & $19.1 \%$ & $17.9 \%(17.0 \%)^{7}$ & $\begin{array}{c}\text { S. Typhi }(8.1 \% ; \\
1.0 \%)^{7} ; S . \text { Paratyphi } \\
(3.0 \% ; 2.0 \%) ; S . \\
\text { Enteritidis }(3.8 \% \text {; } \\
8.9 \%) ; S . \text { Arizona } \\
(3.0 \% ; 5.4 \%)\end{array}$ & $100 \%$ & $80 \%^{8}$ & {$[26]$} \\
\hline Zaria & $\begin{array}{l}12 / 2007- \\
6 / 2008\end{array}$ & $\begin{array}{l}\text { Clinical typhoid } \\
\text { patients }\end{array}$ & 713 & ND & ND & $14.3 \%$ & $\begin{array}{c}S \text {. Typhi }(10.0 \%) ; S . \\
\text { Paratyphi A }(2.1 \%) \text {; } \\
\text { S. Paratyphi B } \\
(2.2 \%)\end{array}$ & $9.9-90.1 \%{ }^{9}$ & Yes & {$[27]$} \\
\hline Oyo state & 2003 & $\begin{array}{l}\text { Clinical typhoid } \\
\text { suspects }\end{array}$ & 100 & $48 \%$ & ND & ND & $\mathrm{ND}$ & ND & ND & {$[28]$} \\
\hline $\begin{array}{l}\text { Akwa Ibom } \\
\text { state }\end{array}$ & ND & $\begin{array}{c}\text { Clinical typhoid } \\
\text { patients }\end{array}$ & 100 & $55.0 \%$ & $39.0 \%$ & $12.0 \%$ & $\begin{array}{l}S . \text { Typhi }(10.0 \%) ; S . \\
\text { Paratyphi }(2.0 \%)\end{array}$ & Yes & $\mathrm{Yes}^{10}$ & [29] \\
\hline Benue state & $\begin{array}{c}11 / 2006- \\
6 / 2007\end{array}$ & Febrile patients & 1479 & $57.9 \%(26.3 \%)^{11}$ & ND & ND & $\mathrm{ND}$ & ND & ND & {$[30]$} \\
\hline Ibadan & $2004-2005$ & $\begin{array}{l}\text { Febrile poultry } \\
\text { farm workers }\end{array}$ & 991 & ND & ND & $3.9 \%$ & $\begin{array}{c}S . \text { Typhi }(0.7 \%) ; S \text {. } \\
\text { Enteritidis }(1.3 \%) ; \\
S . \text { Dublin }(0.7 \%) ; S \text {. } \\
\text { Typhimurium } \\
(0.7 \%) ; \text { other }(0.5 \%)\end{array}$ & $14 \%^{12}$ & No & {$[31]$} \\
\hline Ibadan & 2004 & $\begin{array}{l}\text { HIV seropositive } \\
\text { patients }\end{array}$ & 108 & ND & $11.1 \%$ & $8.3 \%$ & $\begin{array}{c}S . \text { Typhi }(4.6 \%) ; S \\
\text { Paratyphi A }(0.9 \%) \text {; } \\
S . \text { Paratyphi B } \\
(2.7 \%)\end{array}$ & ND & ND & {$[32]$} \\
\hline Owerri & 2005 & Malaria patients & 125 & ND & $35.2 \%$ & $20 \%$ & S. Typhi (20\%) & $\mathrm{ND}$ & ND & [33] \\
\hline Ile-Ife & 1980-1987 & Sepsis & 920 & ND & $25.3 \%$ & $1.5 \%$ & S. Typhi $(1.5 \%)$ & $100^{13}$ & ND & {$[34]$} \\
\hline Ile-Ife & $\begin{array}{l}02 / 1994- \\
01 / 1995 \\
\end{array}$ & $\begin{array}{c}\text { Neonates at risk } \\
\text { of sepsis }\end{array}$ & 107 & ND & $55.0 \%$ & $1.9 \%$ & ND & ND & ND & [35] \\
\hline $\begin{array}{l}\text { Sagamu, Lagos } \\
\text { and Ibadan }\end{array}$ & $\begin{array}{c}11 / 2004- \\
5 / 2005\end{array}$ & $\begin{array}{c}\begin{array}{c}\text { Blood bank } \\
\text { donors }\end{array} \\
\end{array}$ & 200 & $53 \%$ & ND & ND & ND & ND & ND & [36] \\
\hline Ile-Ife & 1989 & $\begin{array}{c}\text { Healthy school } \\
\text { kids }\end{array}$ & 408 & ND & $5.2 \%$ & $2.0 \%$ & ND & ND & ND & {$[37]$} \\
\hline
\end{tabular}

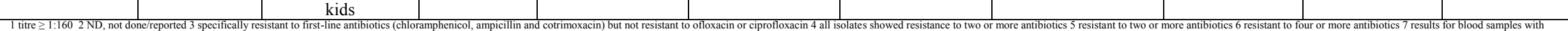

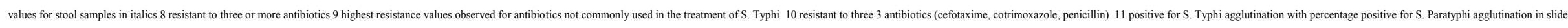
agglutination test in parentheses 12 resistant to streptomycin only 13 resistant to ampicillin and penicillin $\mathrm{G}$ but sensitive to first-line antibiotics 
moisture resistant sachet and may be stored at ambient temperatures for at least two years without the need for refrigeration. Therefore, optimal use is made of the reagent and no excess reagent is lost or exposed to adverse conditions when testing a single patient. Apart from a pipet to apply the serum, no other equipment is required and there is no need for electricity, or special training to perform the test. However, while the evaluation study performed in Indonesia has demonstrated favourable assay characteristics in terms of sensitivity and specificity, further validation is needed to confirm the diagnostic test accuracy for use in countries in Africa. Patient characteristics and epidemiological conditions that can influence accuracy may differ from those in Indonesia. The diagnostic yield of culture is limited and in this study just ten cases that were seropositive in the latex agglutination assay could be confirmed by PCR amplification. However, PCR is not an accepted standard test for typhoid fever diagnosis and therefore further studies are needed to validate the rapid test.

The diagnosis of typhoid fever could be further improved with the development of a better standard test. Blood culture is most effective during the early stages of infection when the pathogen is still circulating in the vascular system and possibly could be improved by the use of automatic culture systems and the addition of resins to absorb antibiotics present in the sample. The culture of bone marrow is more sensitive than blood culture but this method may be used in sophisticated hospitals only, as it is painful for the patient and hence rarely applied [39-41]. Automatic culture systems were not available for use in the present study and the collection of a bone marrow sample was not possible. It is possible the yield of culture could be improved by altering the culture medium. A systematic investigation of the metabolic requirements of Coxiella burnetti has allowed the development of a cell-free culture medium for this fastidious pathogen [42]. Metabolomics may also help to identify volatile metabolites that then may be used as biomarkers in breath analysis $[43,44]$; typhoid patients are known to produce a typical smell of freshly baked brown bread [45]. The diagnostic sensitivity of PCR may be increased by simultaneously testing blood, stool and urine samples [46]. Hatta and Smits showed that the diagnostic yield of blood culture, PCR on blood, PCR on stool, and PCR on urine are $57.1 \%, 78.2 \%, 39.5 \%$ and $65.6 \%$ respectively and that the total diagnostic yield of PCR when applied on three specimens is 95.7\%. Real-time PCR and multiplex PCR may have even higher sensitivities $[47,48]$. It is also possible that the yield of PCR could be improved by using automatic DNA extraction systems.

Essentially all serological tests for typhoid are based on the detection of antibodies to lipopolysaccharide (LPS) antigens (O9 and O12) [12$15,17,49]$. As shown in the lateral flow assay for the detection of $S$. Typhi LPS specific antibodies, antibodies first start to develop at a time when the pathogen is already disappearing from the bloodstream [50]. The natural course and magnitude of the immune response seems to limit the sensitivity of serological testing for typhoid. Proteomic approaches could therefore be useful in identifying novel specific antigens that elicit antibodies at a very early stage of infection and new technologies such as bead-based array technology could help to improve serological testing for typhoid [51].

While further validation of existing point-of-care tests for typhoid and the development of improved diagnostic tools have high priority in the improvement of patient detection and management, control programs composed of providing both clean drinking water supplies and adequate community information to prevent infection, as well as offering vaccination to high-risk groups should also be prioritized [52]. Much attention is given to the socalled group of neglected tropical diseases, but typhoid fever remains one of the most important bacterial infections in developing countries and is thus deserving of equal attention and should be regarded and prioritized as a neglected tropical infectious disease [37].

Our results indicate that typhoid is an important infectious disease in out-patients presenting at health facilities in Lagos and that the introduction of a wellvalidated point-of-care test is urgently needed.

\section{Acknowledgments}

The authors would like to acknowledge the Nigerian Institute of Medical Research for sponsorship of the project and KIT Biomedical Research, Netherlands, for the provision of the Typhi Dri Dot kits.

\section{References}

1. Parry CM, Hien TT, Dougan G, White NJ, Farrar JJ (2002) Typhoid fever. N Engl J Med 347: 1770-1782.

2. House D, Wain J, Ho VA, Diep TS, Chinh NT, Bay PV, Vinh H, Duc M, Parry CM, Dougan G, White NJ, Hien TT, Farrar JJ (2001) Serology of typhoid fever in an area of 
endemicity and its relevance to diagnosis. J Clin Microbiol 39: 1002-1007.

3. Hirose K, Tamura K, Sagara H, Watanabe H (2001) Antibiotic susceptibilities of Salmonella enterica serovar Typhi and $S$. enterica serovar Paratyphi A isolated from patients in Japan. Antimicrob Agents Chemother 45: 956958.

4. Crump JA, Luby SP, Mintz ED (2004) The global burden of typhoid fever. Bull World Health Organ 82: 346-353.

5. Sinha A, Sazawal S, Kumar R, Sood S, Reddaiah VP, Singh B (1999) Typhoid fever in children aged less than 5 years. Lancet 354: 734-737.

6. Brooks WA, Hossain A, Goswami D, Nahar K, Alam K, Ahmed N (2005) Bacteraemic typhoid fever in children in an urban slum, Bangladesh. Emerg Infect Dis 11: 326-329.

7. Siddiqui FJ, Rabbani F, Hasan R, Nizami SQ, Bhutta ZA (2006) Typhoid fever in children: some epidemiological considerations. Int J Infect Dis 10: 215-222.

8. Edelman R and Levine MM (1986) Summary of an International workshop on Typhoid Fever. Rev Infect Dis 8: 329-349.

9. Levine MM, Grados O, Gilman RH, Woodward WE, SolisPlaza R, Waldman W (1978) Diagnostic value of the Widal test in areas endemic for typhoid fever. Am J Trop Med Hyg 27: 795-800.

10. Parry CM, Hoa NT, Diep TS, Wain J, Chinh NT, Vinh H, Hien TT, White NJ, Farrar JJ (1999). Value of a single-tube widal test in diagnosis of typhoid fever in Vietnam. J Clin Microbiol 37: 2882-2286.

11. House D, Chinh NT, Diep TS, Parry CM, Wain J, Dougan G, White NJ, Hien TT, Farrar JJ (2005) Use of paired serum samples for serodiagnosis of typhoid fever. J Clin Microbiol 43: 4889-4890.

12. Prakash P, Sen MR, Mishra OP, Gulati AK, Shukla BN, Nath G (2007) Dot enzyme immunoassay (Typhidot) in diagnosis of typhoid fever in children. J Trop Pediatr 53: 216-217.

13. Lim PL, Tam FC, Cheong YM, Jegathesan M (1998) Onestep 2-minute test to detect typhoid-specific antibodies based on particle separation in tubes. J Clin Microbiol 36: 22712278.

14. Dutta S, Sur D, Manna B, Sen B, Deb AK, Deen JL, Wain J, von Seidlein L, Ochiai L, Clemens JD, Bhattacharya SK (2006) Evaluation of new-generation serologic tests for the diagnosis of typhoid fever: data from a community-based surveillance in Calcutta, India. Diagn Microbiol Infect Dis 4: 359-365.

15. Ochiai RL, Acosta CJ, Danovaro-Holliday MC, Baiqing D, Bhattacharya SK, Agtini MD, Bhutta ZA, Canh do G, Ali M, Shin S, Wain J, Page AL, Albert MJ, Farrar J, AbuElyazeed R, Pang T, Galindo CM, von Seidlein L, Clemens JD, Domi Typhoid Study Group (2008) A study of typhoid fever in five Asian countries: disease burden and implications for controls. Bull World Health Organ 86: 260268.

16. Naheed A, Ram PK, Brooks WA, Mintz ED, Hossain MA, Parsons MM, Luby SP, Breiman RF (2008) Clinical value of Tubex and Typhidot rapid diagnostic tests for typhoid fever in an urban community clinic in Bangladesh. Diagn Microbiol Infect Dis 61: 381-386.

17. Abdoel TH, Pastoor R, Smits HL, Hatta M (2007) Laboratory evaluation of a simple and rapid latex agglutination assay for the serodiagnosis of typhoid fever. Trans Roy Soc Trop Med Hyg 101: 1032-1038.
18. Smith SI, Odunukwe NN, Niemogha MT, Ahmed AO, Efienemokwu CA, Otuonye MN, Bankole M, Junaid M, Agomo C, Mafe AG, Idigbe EO (2004) Diagnostic methods for typhoid fever in Nigeria. Br J Biomed Sci 61: 179-181.

19. Song JH, Cho H, Park MY, Na DS, Moon HB, Pai CH (1993) Detection of Salmonella typhi in the blood of patients with typhoid fever by polymerase chain reaction. J Clin Microbiol 31: 1439-1443.

20. Olukoya DK, Smith SI, Eyitayo CA, Ogunjimi A (2000) Drug resistance and plasmid profile of Salmonella species isolated from different sources in Nigeria. Afr J Clin Exp Microbiol 1: 21-27.

21. Wain J, Diep TS, Ho VA, Walsh AM, Nguyen TT, Parry CM, White NJ (1998) Quantitation of bacteria in blood of typhoid fever patients and relationship between counts and clinical features, transmissibility, and antibiotic resistance. J Clin Microbiol 36: 1683-1687.

22. Oboegbulum SI, Oguike JU, Gugnani HC (1995) Microbiological studies on cases diagnosed as typhoid/enteric fever in south-east Nigeria. J Commun Dis 27: 97-100.

23. Akinyemi KO, Oyefolu AO, Omonigbehin EO, Akinside KA, Coker AO (2000) Evaluation of blood collected from clinical diagnosed typhoid fever patients in the metropolis of Lagos, Nigeria. J Nigerian Infect Contr Association 3: 2530.

24. Akinyemi KO, Coker AO, Olukoya DK, Oyefolu AO, Amorighoye EP, Omonigbehin EO (2000) Prevalence of multi-drug resistant Salmonella typhi among clinically diagnosed typhoid fever patients in Lagos, Nigeria. Z Naturforsch C 55: 489-493.

25. Akinyemi KO, Smith SI, Oyefolu AO, Coker AO (2005) Multidrug resistance in Salmonella enterica serovar typhi isolated from patients with typhoid fever complications in Lagos, Nigeria. Public Health 119:321-327.

26. Akinyemi KO, Bamiro BS, Coker AO (2007) Salmonellosis in Lagos, Nigeria: incidence of Plasmodium falciparumassociated co-infection, patterns of antimicrobial resistance, and emergence of reduced susceptibility to fluoroquinolones. J Health Popul Nutr 25: 351-358.

27. Adeshina GO, Asuagwu NO, Okeke C-LE, Ehinmidu JO, Bolaji RO (2009) Prevalence and susceptibility of Salmonella typhi and Salmonella paratyphi in Zaria, Nigeria. Int J Health Res 2: 355-360.

28. Akinyemi KO, Ilesanmi AO, Fasure AK, Bola-Oyefolu AO (2005) Blood leucocyte count patterns in relation to Salmonella agglutinins among patients with Salmonellosis in Ibidan, Oyo State, Nigeria. Nig J Health Biomed Sci 4: 813.

29. Itah AY and Uweh EE (2005) Bacteria isolated from blood, stool and urine of typhoid patients in a developing country. Southeast Asian J Trop Med Public Health 36: 673-677.

30. Umeh EU and Agbulu CO (2010) Distribution pattern of Salmonella typhoidal serotypes in Benue State Central, Nigeria. Internet J Epidemiol 8: 1-23.

31. Fashae K, Ogunsola F, Aarestrup FM, Hendriksen RS (2010) Antimicrobial susceptibility and serovars of Salmonella from chickens and humans in Ibadan, Nigeria. J Infect Dev Ctries. 4: 484-494.

32. Akinyemi KO, Bola-Oyefolu AO, Adewale A0, Odekanmi AA (2005) Prevalence and antimicrobial susceptibility patterns of septicaemic bacterial agents isolated from blood of confirmed sero-positive HIV-Patients in Ibidan, Nigeria. 
Proc Fac Science, Lagos State University, Ojo, Sept 11-14, 2005.

33. Ukaga CN, Orji CN, Orogwu S, Nwoke BE, Anosike JC, Udujih OS, Onyeka PI, Awujo NC (2006) Concomitant bacteria in the blood of malaria patients in Owerri, southeastern Nigeria. Tanzan Health Res Bull 8: 186-188.

34. Ako-Nai AK, Adejuyigbe EA, Ajayi FM, Onipede AO (1999) The bacteriology of neonatal septicaemia in Ile-Ife, Nigeria. J Trop Pediatr 45: 146-151.

35. Ako-Nai AK, Taiwo O, Ebri A, Adeniran MO (1990) Bacterial isolates involved in cases of septicaemia in a Nigerian hospital. East Afr Med J 67: 407-412.

36. Adias TC, Jeremiah ZA, Ilesanmi AO (2010) Distribution of antibodies to Salmonella in the sera of blood donors in the south-western region of Nigeria. Blood Transfus 8: 163-169.

37. Olusanya O, Shonukan OO, Ogwo VA (1990) Childhood carriers of Salmonella and Shigella species in the rural area of Ile-Ife, Nigeria. Ethiop Med J 28: 49-52.

38. Petti CA, Polage CR, Quinn TC, Ronald AR, Sande MA (2006) Laboratory medicine in Africa: a barrier to effective health care. Clin Infect Dis 42: 377-382.

39. Gilman RH, Terminel M, Levine MM, Hernandez-Mendoza P, Hornick RB (1975) Relative efficacy of blood, urine, rectal swab, bone-marrow, and rose-spot cultures for recovery of Salmonella typhi in typhoid fever. Lancet 1 (7918):1211-1213.

40. Gasem MH, Keuter M, Dolmans WM, Van Der VenJongekrijg J, Djokomoeljanto R, Van Der Meer JW (2003) Persistence of Salmonellae in blood and bone marrow: randomized controlled trial comparing ciprofloxacin and chloramphenicol treatments against enteric fever. Antimicrobial Agents Chemother 47: 1727-1731.

41. Bhutta ZA (2006) Current concepts in the diagnosis and treatment of typhoid fever. BMJ 333: 88-82.

42. Omsland A, Cockrell DC, Howe D, Fischer ER, Virtaneva K, Sturdevant DE, Porcella SF, Heinzen RA (2009) Host cell-free growth of the Q fever bacterium Coxiella burnetii. Proc Natl Acad Sci USA 106: 4430-4434.

43. Louhelainen N, Myllärniemi M, Rahman I, Kinnula VL (2008) Airway biomarkers of the oxidant burden in asthma and chronic obstructive pulmonary disease: current and future perspectives. Int J Chron Obstruct Pulmon Dis 3: 585603.
44. Effros RM (2008) Metabolomics in exhaled breath condensates. Am J Respir Crit Care Med 177: 236.

45. Stitt WZ and Goldsmith A (1995) Scratch and sniff. The dynamic duo. Arch Dermatol 131: 997-999.

46. Hatta M and Smits HL (2007) Detection of Salmonella typhi by nested polymerase chain reaction in blood, urine, and stool samples. Am J Trop Med Hyg 76: 139-193.

47. Massi MN, Shirakawa T, Gotoh A, Bishnu A, Hatta M, Kawabata M (2005) Quantitative detection of Salmonella enterica serovar Typhi from blood of suspected typhoid fever patients by real-time PCR. Int J Med Microbiol 95: 117-120.

48. Kumar A, Balachandran Y, Gupta S, Khare S, Suman (2010) Quick PCR based diagnosis of typhoid using specific genetic markers. Biotechnol Lett (in press).

49. Pastoor R, Hatta M, Abdoel TH, Smits HL (2008) Simple, rapid, and affordable point-of-care test for the serodiagnosis of typhoid fever. Diagn Microbiol Infect Dis 61: 129-134.

50. Waterboer T, Sehr P, Pawlita M (2006) Suppression of nonspecific binding in serological Luminex assays. J Immunol Methods 309: 200-204.

51. Levine MM (2009) Typhoid vaccines ready for implementation. N Engl J Med 361: 403-405.

52. Hatta M, Bakker M, van Beers S, Abdoel TH, Smits HL (2009) Risk Factors for Clinical Typhoid Fever in Villages in Rural South-Sulawesi, Indonesia. Int J Trop Med 4: 9199.

53. Smits HL (2009) Prospects for the control of neglected tropical diseases by mass drug administration. Expert Rev Anti Infect Ther 7: 37-56.

\section{Corresponding author}

Dr. Stella I. Smith

Molecular Biology and Biotechnology Division

Nigerian Institute of Medical Research

6 Edmond Crescent

P.M.B. 2013, Yaba

Lagos, Nigeria

Telephone: + 23414822269

Fax: +23413425171

Email: stellaismith@yahoo.com

Conflict of interests: No conflict of interests is declared. 